\title{
METHODOLOGY FOR THE IMPROVEMENT OF CONTROL FUNCTIONS FOR TRAFFIC OF ROAD VEHICLES USING SYSTEMS OF THE AUTOMATIC RECORDING OF ADMINISTRATIVE VIOLATIONS
}

\author{
Mukhtar Kerimov¹, Ravil Safiullin², Aleksander Afanasyev³ \\ 1,2 Saint Petersburg State University of Architecture and Civil Engineering \\ Vtoraja Krasnoarmejskaja ul. 4, St. Petersburg, Russia \\ ${ }^{3}$ Saint Petersburg Mining University \\ 21st Line, 2, St. Petersburg, Russia \\ safravi@mail.ru²
}

\begin{abstract}
Relevant issues of the implementation of systems of the automatic photo-video recording of administrative violations in the field of ensuring road safety are considered. The promising directions of forming control functions for traffic of road vehicles (RV) using systems of the automated control of transportation vehicles are substantiated. A model of the development of multipurpose automated control systems for traffic of road vehicles is developed. Characterization of life cycle stages with regard to the existing systems of the automated photo-video recording of administrative violations in road traffic taking into account features of their operation is carried out.

A result of the carried out research is a developed technique for the optimal implementation of operational and technical control facilities in the field of ensuring road safety (RS), an obtained dependence of financial expenditures for the maintenance of the complex operability during service life, as well as of a level of decrease in the accident rate at specific sites of the street and road network or individual territorial entities of the Russian Federation.
\end{abstract}

\section{Keywords}

Automatic photo-video recording facilities, administrative violations in road traffic, automated control, life cycle, effectiveness, road vehicles.

\section{Introduction}

One of the criteria of transfer to a new level in the development of road vehicles and technology of their use is the wide-spread implementation of continuous monitoring and conditions of their operation. The development of smart transport systems (STS) is the most promising direction of scientific studies in the world. Such systems provide the possibility of the intelligent interaction with single road vehicles or with a traffic flow by means of information and communication technologies in order to improve the effectiveness of the above-ground transport use and enhance the improvement of road safety (GOST R ISO 14813-1-2011).

\section{Methods}

Ensuring road safety is a complex problem. The practice of the formulation of scientific and technical tasks and managerial decision making in this field gives evidence of the need of accounting the hierarchy of the structure of road and transport systems and technologies being implemented in them, time-to-time variability of street and road network characteristics, technical characteristics of the fleet of road vehicles and probabilistic nature of conditions of their functioning (GOST R ISO 14813-1-2011).

The road and transport accident rate depends on various reasons of technical, technological, organizational, and methodological nature. The analysis of statistical data confirms that reserves of the improvement of the mechanism ensuring road safety by the operational practice are far from being exhausted (Safiullin, Kerimov, 2016). TThe foregoing explains the relevancy of the task to bring the operational control system of the road and transport accident rate in compliance with principles of road safety system management.

A multiple regression analysis was carried out to analyze the influence of various factors on the number of road traffic accidents (RTA) in individual regions of the Russian Federation. The following were accepted as factors: 
- specific index, characterizing the ratio of the number of vehicles to the number of issued regulations on administrative violations $\left(x_{1}\right)$, vehicle/unit;

- the amount of paid traffic tickets* $10^{5}\left(x_{2}\right)$, RUR;

- number of stationary automatic recording facilities $(\mathrm{ARF})\left(x_{3}\right)$, pcs.;

- number of portable ARFs $\left(x_{4}\right)$, pcs.;

- number of transportable ARFs $\left(x_{5}\right)$, pcs.;

- number of mobile ARFs $\left(x_{6}\right)$, pcs.;

- availability of a sign of ARF action $\left(x_{7}\right)$, pcs.;

- population density in the region $\left(x_{8}\right)$, person $/ \mathrm{km}^{2}$;

- transport density in the region $\left(x_{9}\right)$, unit $/ \mathrm{km}^{2}$;

- mileage of automotive roads $\left(x_{10}\right), \mathrm{km}$;

- population of the region*106 $\left(x_{11}\right)$, persons;
- territory of the region $\left(x_{12}\right), \mathrm{km}^{2}$;

- number of vehicles in the region $\left(x_{13}\right)$, units.

The number of RTAs $(Y)$ is accepted as the accident rate index. To analyze the interrelation between the considered parameters, the statistical data for 2014 characterizing the influence of various factors on road safety in regions under study are used: Moscow, Moscow Region, Saint Petersburg, Leningrad Region, the Republic of Tatarstan, Voronezh Region, Saratov Region (Table 1).

The analysis shows that factors $x_{9}, x_{10}$ and $x_{12}$ have the maximum influence on the RTA index. Factor $x 11$ has the greatest influence, on which the RTA number depends by $88.4 \%$, i.e. $0.942=0.884$. Other factors are less significant (Safiullin et al., 2016).

Table 1. Statistical data characterizing the influence of factors on road safety

\begin{tabular}{|c|c|c|c|c|c|c|c|}
\hline Factors & $\begin{array}{c}\text { Voronezh } \\
\text { Region }\end{array}$ & Moscow & $\begin{array}{c}\text { Moscow } \\
\text { Region }\end{array}$ & $\begin{array}{c}\text { Saint } \\
\text { Petersburg }\end{array}$ & $\begin{array}{c}\text { Leningrad } \\
\text { Region }\end{array}$ & $\begin{array}{c}\text { Republic of } \\
\text { Tatarstan }\end{array}$ & $\begin{array}{c}\text { Saratov } \\
\text { Region }\end{array}$ \\
\hline RTA & 3,555 & 11,312 & 9,042 & 8,222 & 4,074 & 5,399 & 3,101 \\
\hline$x_{1}$ & 3.62 & 12.23 & 5.90 & 1.76 & 1.13 & 7.82 & 0.99 \\
\hline$x_{2}$ & $1,127.65$ & $5,490.53$ & $1,100.32$ & 329.66 & 255.88 & $2,892.65$ & 224.65 \\
\hline$x_{3}$ & 39 & 708 & 186 & 66 & 66 & 201 & 26 \\
\hline$x_{4}$ & 62 & 301 & 15 & 22 & 22 & 296 & 49 \\
\hline$x_{5}$ & 1 & 5 & 0 & 0 & 0 & 0 & 0 \\
\hline$x_{6}$ & 1 & 0 & 8 & 0 & 0 & 17 & 1 \\
\hline$x_{7}$ & 38 & 70 & 89 & 75 & 75 & 39 & 42 \\
\hline$x_{8}$ & 44.60 & $4,822.10$ & 160.70 & $3,566.70$ & 21.02 & 56.57 & 24.66 \\
\hline$x_{9}$ & 13.72 & 261.50 & 18.22 & 521.63 & 8.13 & 9.14 & 6.73 \\
\hline$x_{10}$ & 11,602 & 737 & 27,229 & 531 & 13,662 & 22,267 & 11,799 \\
\hline$x_{11}$ & 2.33 & 13.11 & 7.33 & 5.13 & 1.70 & 3.84 & 2.50 \\
\hline$x_{12}$ & 52,216 & 2,511 & 44,379 & 1,439 & 83,008 & 67,847 & 101,240 \\
\hline$x_{13}$ & 716,388 & 656,766 & 808,847 & 750,623 & 682,385 & 620,688 & 681,453 \\
\hline
\end{tabular}

Table 2. Correlation between various indices influencing road safety in regions under study

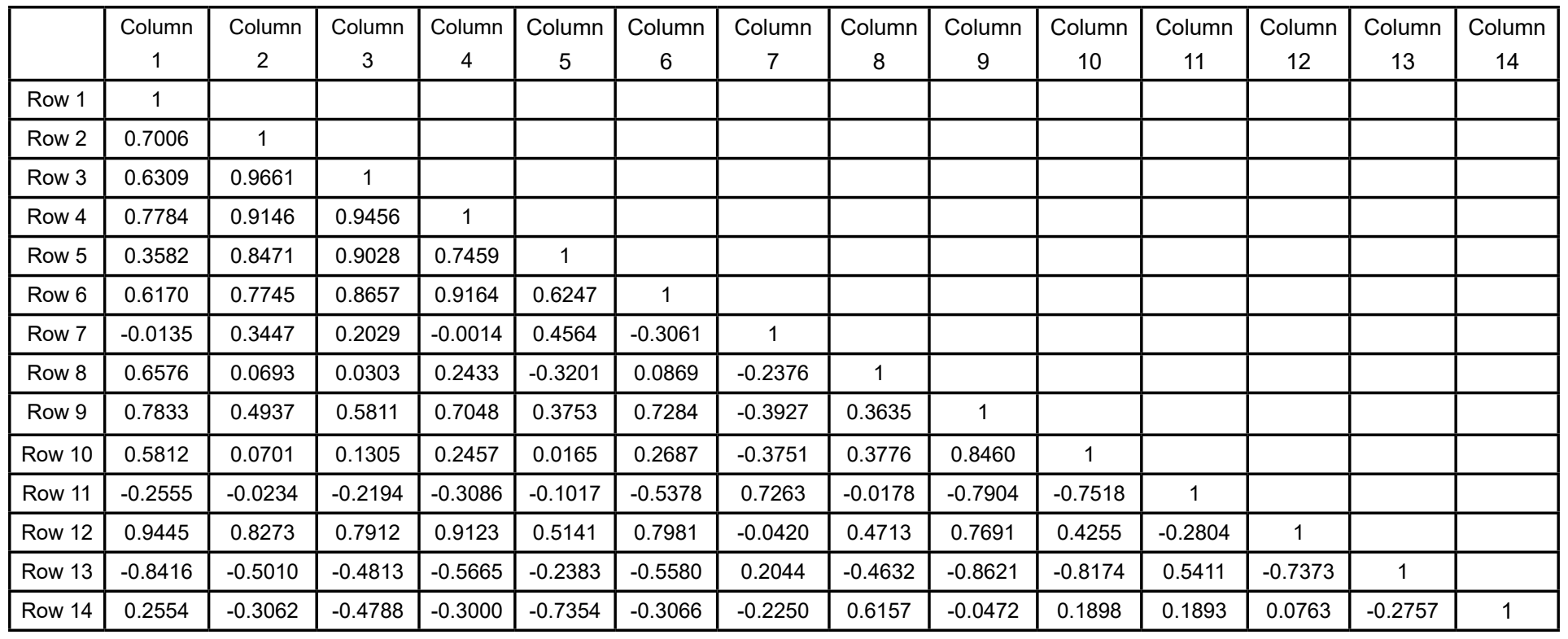


It can be seen from the correlation table that some factors are correlated. For example, factors $x_{1}$ and $x_{2}$ have a relation estimated by the value of 0.96 , and $x_{2}$ and $x_{3}$ - by the value of 0.95 . Practically all factors have the positive correlation with RTAs, i.e. their increase leads to the increase in the RTA number.

Factors $x_{6}, x_{10}$ and $x_{12}$ have a negative correlation with RTAs, their increase leads to the decrease in the RTA number. A multiple regression analysis of the influence of factors $x_{8}, x_{9}$ and $x_{11}$ on the RTA number was carried out according to the Stat graphics program.

Table 2 presents statistical characteristics of the obtained dependence: equation factors, estimates of their reliability by t-criterion, the analysis of the influence degree of factors on the dependent variable (i.e. coefficients of multiple determination).

All coefficients are statistically significant and describe the influence on the dependent variable by $94.4 \%$.

Table 3. Statistical characteristics of the obtained mathematical model

\begin{tabular}{|c|c|c|c|c|}
\hline & & Standard & $T$ & \\
\hline Parameter & Estimate & Error & Statistic & $P$-Value \\
\hline CONSTANT & $1,326.05$ & 698.759 & 1.89772 & 0.1540 \\
\hline$x_{8}$ & -1.09546 & 0.528357 & -2.07333 & 0.1298 \\
\hline$x_{9}$ & 10.5527 & 3.81843 & 2.76361 & 0.0699 \\
\hline$x_{11}$ & $1,033.04$ & 172.974 & 5.97221 & 0.0094 \\
\hline
\end{tabular}

The mathematical model has the following form:

$y=1326,05-1,09546 * x_{8}+10,5527 * x_{9}+1033,04 * x_{1}$

By the degree of influence, factors have the following arrangement: $x_{8}, x_{11}, x_{9}$. The influence of factors is statistically significant.

The influence of factors $x_{1}, x_{2}, x_{3}$ and $x_{8}$ on RTAs has also a good statistically significant model:

$y=2379,24+1543,63 * x_{1}-3,9134 * x_{2}+9,4035 * x_{3}+1,0307 * x_{8}$

Statistical characteristics of the obtained model are presented in Table 4.

Table 4. Statistical characteristics of the mathematical model

\begin{tabular}{|c|c|c|c|c|}
\hline & & Standard & $T$ & \\
\hline Parameter & Estimate & Error & Statistic & $P$-Value \\
\hline CONSTANT & $2,379.24$ & 377.889 & 6.29614 & 0.0243 \\
\hline $\mathrm{x}_{1}$ & $1,543.63$ & 193.139 & 7.99232 & 0.0153 \\
\hline $\mathrm{x}_{2}$ & -3.91341 & 0.472106 & -8.28924 & 0.0142 \\
\hline $\mathrm{x}_{3}$ & 9.40355 & 3.09578 & 3.03754 & 0.0934 \\
\hline $\mathrm{x}_{8}$ & 1.0307 & 0.153725 & 6.70487 & 0.0215 \\
\hline
\end{tabular}

The developed mathematical model shows the dependence of the RTA number on factors $x_{1}, x_{2}, x_{n}$. The specified factors affect the management, technological and methodological aspects of the problem - tightening of road traffic regulations (RTR). The analysis of the obtained model shows that the main contribution to the accident rate is made by the number of registered transportation vehicles in a specific region $-x_{1}$. The specified factor is considered in the model through a standard indicator - the number of vehicles per one photo-video recording (PVR) device. The recommended provision of the region with the automatic recording facilities is one complex per 6,500 transportation vehicles (Safiullin, Vorozhejkin, 2016; Kerimov, 2015).

\section{Main Body}

Life cycle stages of the facilities of automatic photo-video recording of RVR violations are presented in Figure 1.

The developed diagram of the life cycle of automatic photo-video recording facilities includes four stages (Ker-

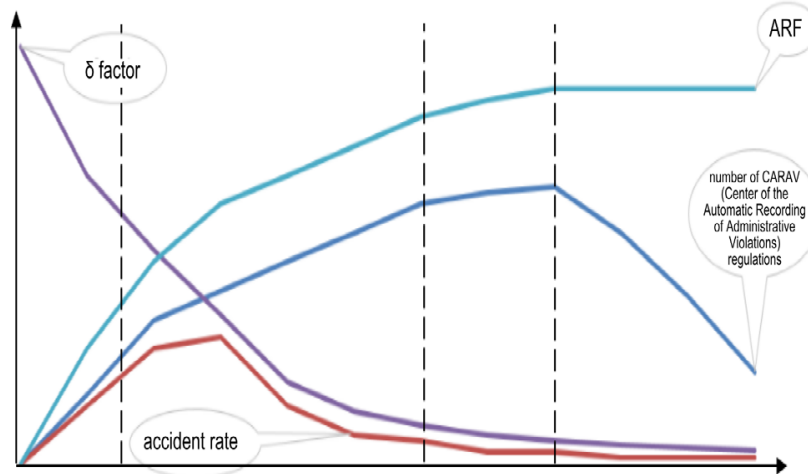

I II III IV

Figure 1. ARF life cycle diagram

imov, 2015).

Stage 1 - "local influence on the accident rate", whereon the increase in a number of systems of photo-video recording and debugging of their operation take place. At this stage, a noticeable growth of the revealed violations occurs. A result is a decrease in the accident rate in places of system location, however, the influence on the total accident rate turns out to be insignificant (Safiullin, Kerimov, 2016).

Stage 2 - "beginning of the system influence on the accident rate", at which ARF have stable operation. A number of systems is constantly increasing, a choice of places for installation is carried out on the basis of the focal analysis of RTAs. The detectability of violations of road traffic regulations increases. The influence on the accident rate on street sections equipped with ARFs is observed. The application of simulants and signal simulators is possible to improve the effectiveness of the ARF system at this stage. It is also necessary to apply operating systems of photo-video recording periodically in places of their use.

Stage 3 - "period of increase in the system influence of ARFs on the accident rat". A gradual decrease in the 
number of revealed administrative violations is observed at this stage, since the level of awareness of drivers of wide-spread control of traffic increases. As a consequence, the accident rate decreases. At the same time, the increase in the number of ARFs continues. Systems are installed in all newly revealed accident clusters and potentially dangerous locations and reach a required value at the end of the stage.

Stage 4 - "period of stable operation of a photo-video recording system", whereby the stabilization of all indices occurs. Therefore, further increase in the number of photo-video recording systems is inexpedient (Safiullin et al., 2016). When implementing these facilities in regions of the Russian Federation, flooding with photo-video recording systems is observed, and afterwards their effectiveness decreases. Accordingly, tasks and targets of their application as well as possibilities of these systems have to be changed. In this regard, the further development of the ARF interaction with smart on-board systems of automotive vehicles is of great importance.

An information and analysis system (IAS) and recommendations for its development are proposed to improve information exchange between smart on-board systems of automotive vehicles and automatic photo-video recording facilities (Figure 2).

The information and analysis system of interaction of smart on-board transport systems (SOBTS) with automatic photo-video recording facilities will allow ensuring the effectiveness of road vehicle use, improve road safety, solve social tasks on transportation performance and reduce environmental loads due to the extension of ARF functional capabilities (Safiullin,Vorozhejkin, 2016). A mechanism of the interaction of this system with the transportation vehicle is shown in Figure 3.

The mechanism of interaction lies in the transfer of two information flows from RVs to the IAS. The external flow of

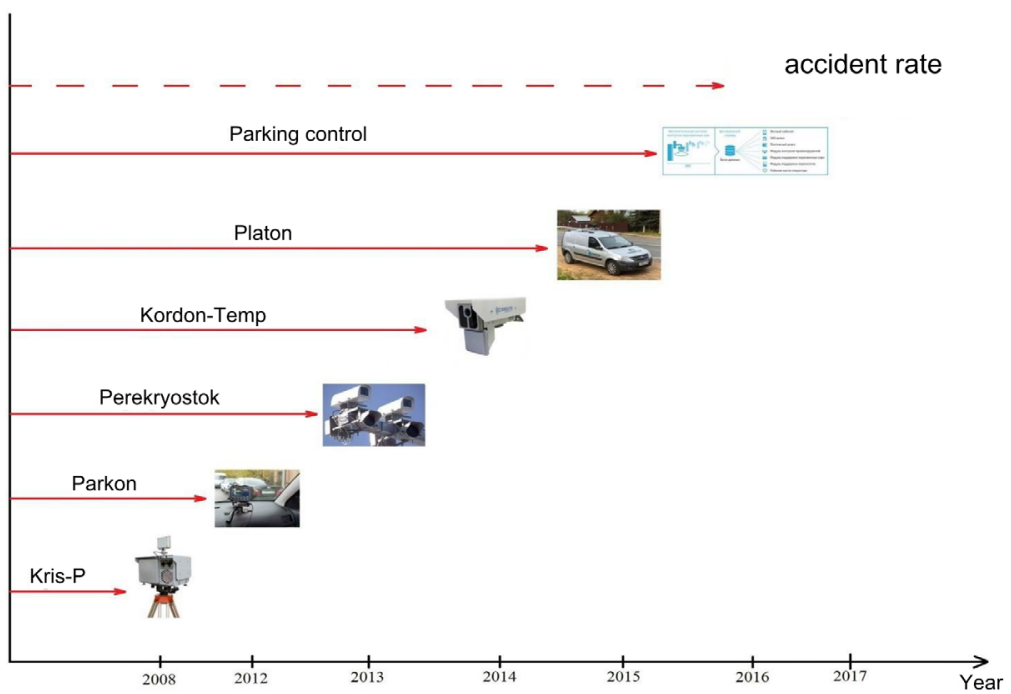

Figure 2. Development of automatic photo-video recording facilities in the territory of the Russian Federation

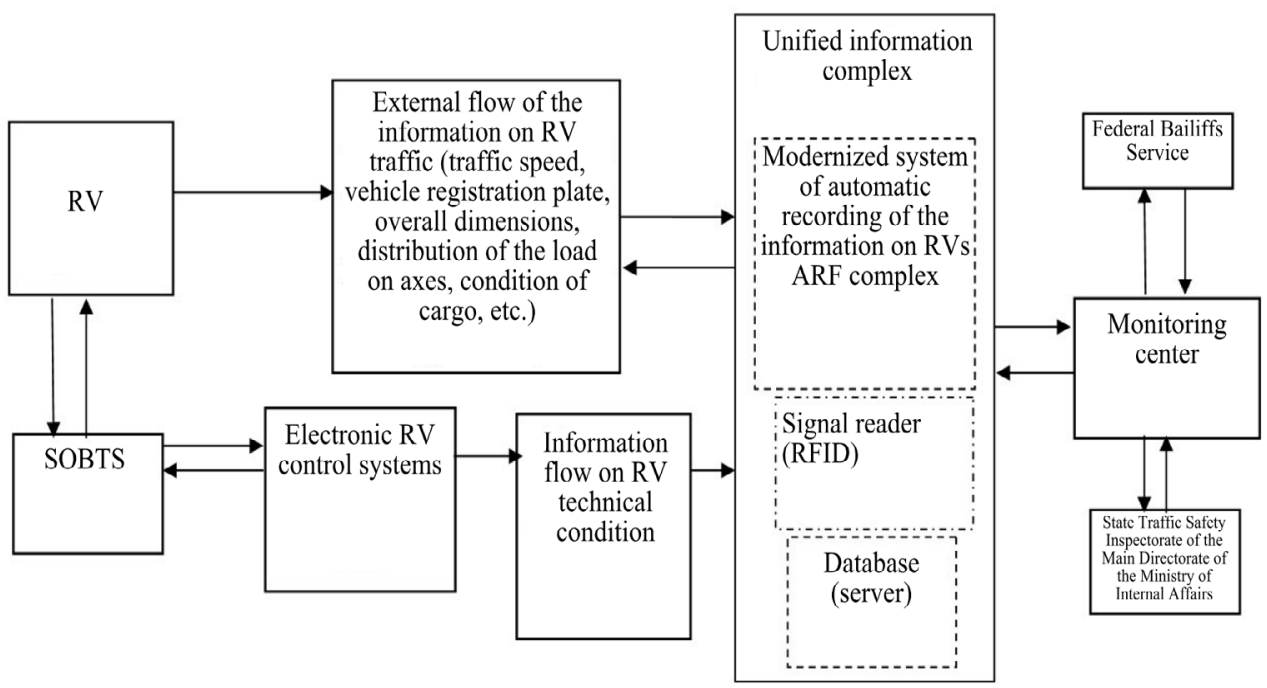

Figure 3. Mechanism of the interaction of the information and analisys system with road vehicles 
information carries data on the vehicle movement (namely, vehicle registration plate, movement speed, RV dimensions, etc.). After information processing by the system and verification according to databases of state authorities, the system, in its turn, transmits a backward signal to a RV, which can carry information about probable discomfort traffic on the way of further running, a warning about the necessity to reduce the speed, a notice about violation of parking rules, etc. (Safiullin, Belikova, 2015).

Table 5. Functional capabilities of the multipurpose information and analysis system

\begin{tabular}{|c|c|}
\hline Function & Description \\
\hline $\mathrm{F}_{1}$ & Compulsory speed limitation \\
\hline $\mathrm{F}_{2}$ & $\begin{array}{c}\text { Verification according to databases of RVs } \\
\text { being on the wanted list }\end{array}$ \\
\hline $\mathrm{F}_{3}$ & $\begin{array}{l}\text { Compulsory stop upon actuation of a red } \\
\text { traffic light }\end{array}$ \\
\hline $\mathrm{F}_{4}$ & Transfer of the identification number \\
\hline$F_{5}$ & $\begin{array}{l}\text { Transfer of the information about the RV } \\
\text { driving speed at the given moment }\end{array}$ \\
\hline $\mathrm{F}_{5^{\prime}}$ & $\begin{array}{l}\text { Transfer of the information about the RV } \\
\text { driving speed for a certain section }\end{array}$ \\
\hline $\mathrm{F}_{6}$ & $\begin{array}{c}\text { Transfer of the information about the RV } \\
\text { technical condition }\end{array}$ \\
\hline
\end{tabular}

The difference of this system from the existing ones lies in the possibility of carrying out the information exchange in the duplex mode and exercising influence on $\mathrm{RV}$, which will make these systems much more effective in comparison with the systems, which are functioning at present.

Table 6 presents existing and prospective functional capabilities of automatic photo-video recording facilities in the territory of the Russian Federation.

Table 6. Existing and prospective functional capabilities of automatic photo-video recording facilities

\begin{tabular}{|c|c|}
\hline $\begin{array}{c}\text { Functions of automatic } \\
\text { photo-video recording } \\
\text { facilities (existing) }\end{array}$ & $\begin{array}{c}\text { Functions of automatic photo-video } \\
\text { recording facilities (prospective) }\end{array}$ \\
\hline $\mathrm{F}_{5}$ & $\mathrm{~F}_{1}$ \\
\hline $\mathrm{F}_{5^{\prime}}$ & $\mathrm{F}_{2}$ \\
\hline & $\mathrm{F}_{3}$ \\
\hline & $\mathrm{F}_{4}$ \\
\hline & $\mathrm{F}_{6}$ \\
\hline & $\mathrm{F}_{\mathrm{n}}$ \\
\hline
\end{tabular}

On the basis of the analysis of these functions, a model of the development of multipurpose systems of automated control of RV traffic was developed, which has the following form (Safiullin, Kerimov, 2017):

$$
\mathrm{W}_{1}=f\left(F_{5}, F_{5}\right) \rightarrow \mathrm{W}=f\left(F_{1}, F_{2}, F_{3}, F_{4}, F_{5}, F_{5}, F_{6}, \ldots, F \mathrm{n}\right),
$$

where $W_{1}$ - function of parameters operating at the given moment; $W$ - function of those parameters to be reached (prospective).

The assessment of the influence of facilities of automatic recording of violations of road traffic regulations on the accident rate can be carried out according to the developed diagram of the sequence of the determination of ARF application effectiveness presented in Figure 4. The following designations are accepted in the diagram:

$C_{o p}$-ARF operation cost, RUR;

$C_{C}$ - cost of one ARF complex, RUR;

$\eta_{O R}$ - rate of allocations for $\mathrm{M}$ (maintenance) and OR (operating repair) of ARFs per year, \%.

$A_{i c}-$ ARF assembly of ARFs, installation and adjustment of a complex, RUR;

$S_{o p}$ - salary of operators, RUR;

$S_{\text {tech }}^{o p}-$ salary of technicians, RUR; $S_{d r}-$ salary of RV drivers, RUR;

$P$ - the number of ARF, pcs.;

$C_{M}$ - cost of annual maintenance, RUR per year;

$i$ - rate on credit, \%; $n$ - service life, per year

$S I_{s c c c}$ - specific capital investments for the construction of a speed control complex, RUR;

$S I_{A R \text { Finstallation }}$ - specific capital investments for the installation of an ARF, RUR;

$k_{2}-$ coefficient of the increase in expenditures for ARFs;

$E_{S I G N}$ - expenditures for a road sign, RUR;

$E_{\text {SIGNinstallation }}$ - expenditures for the installation of a road sign, RUR;

$m$ - the number of road signs, pcs.

$\mathrm{D}_{\mathrm{RTA}}^{\mathrm{b}}$ - damage from RTA in the basic version, RUR;

$N_{\mathrm{RTA}}^{\mathrm{c}}-$ annual RTA number in the basic version, units;

$\mathrm{D}_{\mathrm{RTA}}^{\mathrm{p}}$ - damage from RTA in the projected version, RUR;

$N_{\mathrm{RTA}}^{\mathrm{p}}-$ annual RTA number in the projected version, units;

$\delta_{1}, \delta_{2}, \delta_{3}-$ ARF influence on road safety according to the following rates: RTA number, the number of wounded, the number of fatalities.

\section{Conclusion}

In order to assess the influence of the automatic recording system on road safety, it is necessary to carry out the study at two levels: at the first level, it is necessary to carry out the absolute assessment of RTAs; at the second level, it is necessary to analyze the influence of automatic recording systems on the RTA number from the viewpoint of a place of RTA occurrence and types [5]. The implementation of "the correlation recording system" allows assessing in practice the efficiency of use of various technical facilities of automatic recording of violations of road traffic regulations, as well as a degree of their influence on 


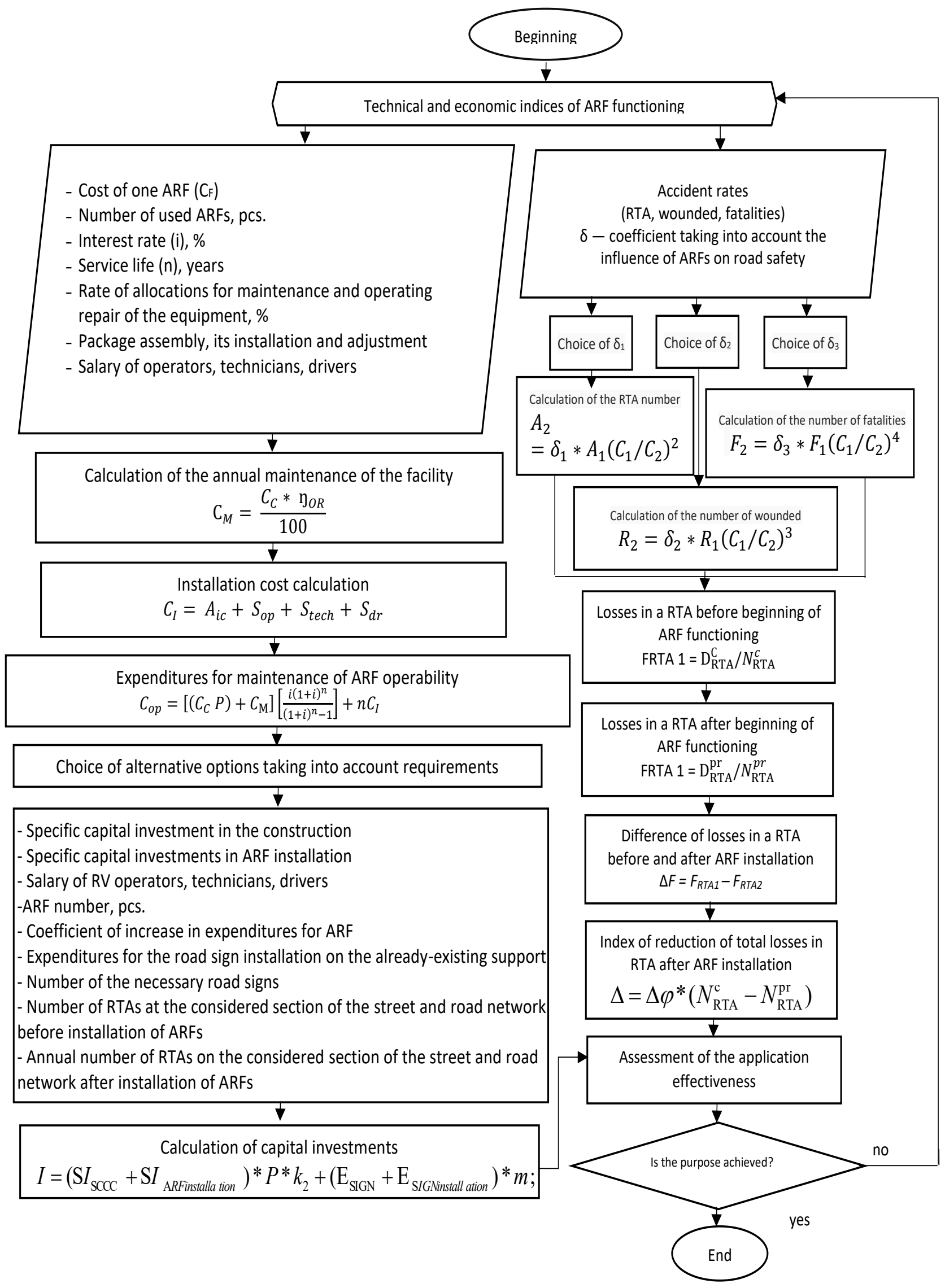

Figure 4. Diagram of the sequence allowing to determine the effectiveness of the application of automatic photo-video recording facilities for recording of administrative violations in road traffic 
the accident rates. The formulated scientific and technical task is solved with the use of methods and software tools implementing the developed systemic criterion (Safiullin et al., 2015; Safiullin et al., 2016; Safiullin, Kerimov, 2017).

\section{Summary}

Based on the carried out study, the methodological approaches for the improvement of traffic control functions when using automatic recording systems, determining their effective application, are defined. The mathematical model of ARF effectiveness assessment upon realization of administrative procedures for traffic control in order to improve road safety is developed.

The ARF life cycle is determined. The information and analysis system of the interaction of smart on-board systems of automotive vehicles with automatic photo-video recording facilities is developed.

The specified system will allow determining the development model of multipurpose systems of automated traffic control to ensure the effectiveness of the use of the above-ground transport due to the extension of ARF functional capabilities. 


\section{References}

GOST R ISO 14813-1-2011 (2012). Intellektual'nye transportnye sistemy. Shema postroenija arhitektury intellektual'nyh transportnyh sistem. Servisnye domeny v oblasti intellektual'nyh transportnyh sistem, servisnye gruppy i servisy [Intelligent transport systems. The scheme to build the architecture of intelligent transport systems. Service domains in the field of intelligent transport systems, service groups and services]. Moscow: Standartinform, p. 120. (in Russian)

Kerimov, M.A. (2015). Metodologicheskie osnovy vybora sredstv avtomaticheskoj fiksacii narushenij PDD [Methodological basis of auto-commit traffic violations]. In: Proceedings of the all-Russian Conference "Problems of the systems and vehicles study". Tula: Tula State University, part 1, pp. 107-110. (in Russian)

Safiullin, R.N., Belikova D.D. (2015). K pravovym voprosam primenenija avtomatizirovannoj sistemy fotovideofiksacii narushenij PDD v RF [To the legal issues of using the automated system of photo-video fixing of traffic regulations in the Russan Federation]. Vestnik grazhdanskikh inzhenerov [Bulletin of Civil Engineers], 2(49), pp. 121-126. (in Russian)

Safiullin, R.N., Kerimov, M. A. (2017a). Metodologicheskij podhod k formirovaniju i ocenke sistemy avtomatizirovannogo kontrolja transportnyh sredstv [Methodological approach to the formation and evaluation of the system of vehicles' automated control]. Vestnik grazhdanskikh inzhenerov [Bulletin of Civil Engineers], 1(60), pp. 246-252. (in Russian)

Safiullin, R.N., Kerimov, M. A. (2017b). Sovershenstvovanie kontrol'nyh funkcij sredstv avtomaticheskoj fotovideofiksacii administrativnyh narushenij avtomobil'nogo transporta [Improvement of control functions of automatic photovideo fixing of administrative violations of motor transport]. In: Proceedings of $X$ International conference "Organization and road safety" . Tyumen: Tyumen industrial University, pp.387-392. (in Russian)

Safiullin, R.N., Kerimov, M.A., Marusin, A.V. (2017). Evaluation of Functional Efficiency of Automated Traffic Enforcement Systems. Transportation Research Procedia, 20, pp. 288-294. DOI: 10.1016/j.trpro.2017.01.025

Safiullin, R.N., Kerimov, M.A., Marusin A.V. (2015). O modelirovanii dorozhno-transportnoj avarijnosti pri ispol'zovanii tehnicheskih sredstv kontrolja narushenij PDD [On the modeling of traffic accidents with the use of technical means of monitoring traffic violations]. Prague: Publishing House "Education and Science", pp. 17-22. (in Russian)

Safiullin, R.N., Kerimov, M.A. (2016). Sredstva fotovideofiksacii narushenij PDD: normativnoe regulirovanie i praktika primenenija. [Means of photo-video fixation of traffic violations: regulatory regulation and practice of application]. Moscow: Direkt-Media, p. 355. (in Russian)

Safiullin, R.N., Kerimov, M.A., Marusin, A.V. (2016). Povyshenie jeffektivnosti sistemy fotovideofiksacii administrativnyh pravonarushenij $v$ dorozhnom dvizhenii [Improving the efficiency of the system of photo and video fixation administrative offences in road traffic]. Vestnik grazhdanskikh inzhenerov [Bulletin of Civil Engineers], 3 (56), pp. 233-237. (in Russian)

Safiullin, R.N., Vorozhejkin, I.V. (2016). Perspektivy razvitija avtomatizirovannoj sistemy fotovideofiksacii administrativnyh narushenij v RF s cel'ju sozdanija informacionno-analiticheskoj sistemy vzaimodejstvija s intellektual'nymi bortovymi transportnymi sistemami [Prospects of development of the automated system of photo and video recordings of administrative violations of the Russian Federation with the aim of creating information-analytical system of interaction with intelligent onboard transportation systems]. Voronezh: Voronezh State University of Forestry and Technologies, vol. 1, pp. 342-347. (in Russian) 